\title{
Apparent digestibility and nitrogen balance in goats given different levels of crushed whole soya beans
}

\author{
C. T. Kadzere and R. Jingura \\ Department of Animal Science, Faculty of Agriculture, University of Zimbabwe, PO Box 167, Harare, Zimbabwe
}

\section{Introduction}

Efficiency of utilization of crude fat (ether extract) in ruminant diets is controversial (Van der Honing and Tamminga, 1986; Zinn, 1989).

Interactions between fat and other nutrients in the gastrointestinal tract may affect not only fat utilization but also digestion of other nutrients, especially crude fibre (Borgstrom, 1974 and Kadzere and Molnar, 1989). The objective of this study was to evaluate the effects of level of inclusion of crushed raw whole soya beans in goat diets on apparent digestibility of crude nutrients and nitrogen balance.

\section{Material and methods}

Sixteen growing castrated male indigenous goats (20 months old, average live weight $17 \pm 4.5 \mathrm{~kg}$ ) were divided into four groups of four goats each, and given diets based on Katambora Rhodes grass (Chloris gayana) and maize containing either 0, 150, 300 or $450 \mathrm{~g} / \mathrm{kg}$ crushed whole soya beans (diets 1,2 , 3 and 4 (Table 1), respectively) for 30 days divided into 23-day adjustment and 7-day collection periods.

Table 1 Ingredients in the experimental concentrate diets $(\mathrm{g} / \mathrm{kg}$ as fed)

\begin{tabular}{lrrrr}
\hline \hline & \multicolumn{4}{c}{ Diet } \\
\cline { 2 - 5 } Ingredient & \multicolumn{1}{c}{1} & 2 & 3 & 4 \\
\cline { 2 - 5 } Maize & 846 & 719 & 592 & 466 \\
Soya bean & 0 & 127 & 254 & 380 \\
Groundnut hulls & 42 & 42 & 42 & 42 \\
Dairy concentrate & 56 & 56 & 56 & 56 \\
Calcium carbonate & 21 & 21 & 21 & 21 \\
Monocalcium phosphate & 14 & 14 & 14 & 14 \\
Urea & 14 & 14 & 14 & 14 \\
Vitamin and salt mix & 7 & 7 & 7 & 7 \\
\hline \hline
\end{tabular}

Two days before putting the animals in individual metabolism cages, goats were treated for internal parasites.

At each feeding time, 08.00 and $15.00 \mathrm{~h}, 200 \mathrm{~g}$ of the respective diet, and $175 \mathrm{~g}$ ground Katambora Rhodes grass hay were added to the feeding trough of each goat. Goats had free access to water throughout the experiment. Apparent nutrient digestibility and nitrogen balance were determined from days 24 to 30.

Food, faeces and urine samples were stored at $-4^{\circ} \mathrm{C}$ during the collection phase until chemical analysis were carried out using the Weende-Method described by Nauman and Bassler (1976).

Data were subjected to analysis of variance and tested for significance among groups using the $t$ test (Steel and Torrie, 1960).

\section{Results and discussion}

Substitution of crushed, whole soya beans for maize in the experimental diets led to an increase in both crude fat and crude protein content of the diets (Table 2).

Table 2 Composition of the hay and concentrate diets $(\mathrm{g} / \mathrm{kg} d r y$ matter)

\begin{tabular}{lrrrrr}
\hline \hline & & \multicolumn{4}{c}{ Diet } \\
\cline { 3 - 6 } Nutrient & Hay & 1 & 2 & 3 & 4 \\
\hline Dry matter & 996 & 984 & 986 & 986 & 987 \\
Crude protein & 47 & 75 & 101 & 116 & 134 \\
Crude fibre & 370 & 218 & 204 & 205 & 205 \\
Crude fat & 18 & 28 & 31 & 44 & 52 \\
Crude ash & 63 & 63 & 64 & 68 & 65 \\
\hline \hline
\end{tabular}


Table 3 Effect of lenel of crusilud whole soya beans on apparent digestibility of crude nutrients and nitrogen retention by goats (no. = 4)

\begin{tabular}{|c|c|c|c|c|c|c|c|c|}
\hline \multirow[b]{3}{*}{ Nutrient } & & \multicolumn{6}{|c|}{ Diet } & \\
\hline & \multicolumn{2}{|c|}{1} & \multicolumn{2}{|c|}{2} & \multicolumn{2}{|c|}{3} & \multicolumn{2}{|c|}{4} \\
\hline & Mean & s.d. & Mean & s.d. & Mean & s.d. & Mean & s.d. \\
\hline $\begin{array}{l}\text { Crude protein } \\
\text { Crude fibre } \\
\text { Crude fat } \\
\text { N-retained (g/day) }\end{array}$ & $\begin{array}{c}52 \cdot 8^{a} \\
57 \cdot 7^{a} \\
56 \cdot 7^{a} \\
2 \cdot 0\end{array}$ & $\begin{array}{l}7 \cdot 8 \\
2 \cdot 1 \\
9.4 \\
1.8\end{array}$ & $\begin{array}{r}54 \cdot 2^{\mathrm{a}} \\
54 \cdot 1^{\mathrm{a}} \\
61 \cdot 3^{\mathrm{a}} \\
3 \cdot 3^{\mathrm{a}}\end{array}$ & $\begin{array}{l}3.6 \\
2 \cdot 4 \\
6 \cdot 1 \\
0.9\end{array}$ & $\begin{array}{c}68 \cdot 8^{\mathrm{b}} \\
50 \cdot 3^{\mathrm{b}} \\
70 \cdot 1^{\mathrm{a}} \\
5 \cdot 4^{\mathrm{ab}}\end{array}$ & $\begin{array}{l}8 \cdot 0 \\
2 \cdot 2 \\
9 \cdot 1 \\
2 \cdot 9\end{array}$ & $\begin{array}{l}75 \cdot 3^{b} \\
44 \cdot 1^{b} \\
87 \cdot 2^{b} \\
6 \cdot 8^{b}\end{array}$ & $\begin{array}{r}13 \cdot 5 \\
4 \cdot 0 \\
4 \cdot 3 \\
3 \cdot 2\end{array}$ \\
\hline
\end{tabular}

a,b ldentical superscripts within a row indicate non-significant differences between groups $(P>0.05)$.

Apparent digestibility (Table 3 ) of crude protein increased parallel to increasing protein and fat content of the diets although Davenport, Boling, Gay and Bunting (1987) reported that dietary fat has no direct effect on the digestibility of crude protein in ruminant diets. Apparent digestibility of ether extract increased parallel to the fat content of the diet. This result contrasts with that of Zinn (1989), who found that the apparent digestibility coefficients of crude fat were 0.801 and 0.690 for steer diets containing 40 and $80 \mathrm{~g} / \mathrm{kg}$ fat, respectively. The current finding is that there is an increase in the apparent digestibility of crude fat in ruminant diets with increasing level of dietary fat from 27 to $52 \mathrm{~g} / \mathrm{kg}$.

There was a significant decrease $(P<0.05)$ in the apparent digestibility of crude fibre with increased dietary fat content; this finding is consistent with reports in literature.

Nitrogen balance increased significantly $(P<0.05)$ with increases in the nitrogen and fat content of the food.

\section{References}

Borgstrom, B. 1974. Fat digestion and absorption. In Biomembranes 4B, pp. 555-620, Plenum Press, New York.
Davenport, G., Boling, J., Gay, N. and Bunting, L. 1987. Effect of soyabean lipid on growth and ruminal nitrogen metabolism in cattle fed soyabean meal or ground whole soyabean. Journal of Animal Science 65: 1680.

Kadzere, C. and Molnar, S. 1989. Untersuchungen zu interaktionen zwischen fetten und calciumcarbonat bzw. dicalciumphosphatzusatz bei verabreichung lipidreicher rationen an wachsende schweine. Journal of Food Scicnce and Technology 91: 135-148.

Nauman, K. and Bassler, R. 1976. Mcthodebuch band III. pp. 3.1, 4.1, 5.1.1, 6.1.1., 8.1. Verlag, Neumaun, Neudanem.

Steel, R. G. D. and Torrie, J. H. 1960. Principles and procedures of statistics. pp. 109-110, 444-445. McGraw Hill, New York.

Van der Honing, Y. and Tamminga, S. 1986. Effect of fat on rumen fermentation and gastrointestinal absorption. In $\mathrm{Nerv}$ developments and future perspectives in research on rumen functions (ed. A. Neimann-Sorensen), 10054 EN, publication Commission European Community. Porsogsanlaeg foulum, Denmark: 55.

Zinn, R. A. 1989. Influence of level and source of dietary fat on its comparative feeding value in finishing diets for steers: feedlot cattle growth and performance. Journal of Animal Science 67: 1029. 